Primljen / Received: 11.7.2017. Ispravljen / Corrected: 17.11.2017.

Prihvaćen / Accepted: 24.11.2017. Dostupno online / Available online: 10.1.2018.

\section{Shear breakout capacity of various fastening systems in concrete elements}

Authors:

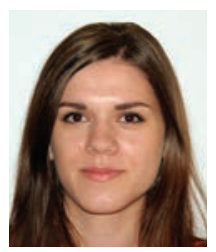

Natalija Bede, PhD. CE

University of Rijeka

Faculty of Civil Engineering

natalija.bede@uniri.hr

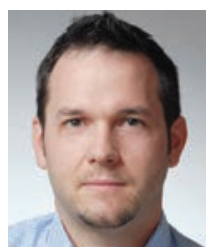

Philipp Grosser, PhD. CE

Hilti, Schaan, Liechtenstein

Philipp.Grosser@hilti.com

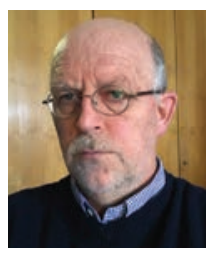

Prof. Joško Ožbolt, PhD. CE

University of Stuttgart

Institute for Building Materials

ozbolt@iwb.uni-stuttgart.de
Preliminary report

\section{Natalija Bede, Philipp Grosser, Joško Ožbolt}

\section{Shear breakout capacity of various fastening systems in concrete elements}

The results of a test program carried out to investigate the difference in the concrete breakout capacity of various fastening systems installed parallel to the edge of a concrete member, and loaded in shear towards the edge of the concrete member, are presented and analysed. According to the current design recommendations, the calculated concrete breakout capacity of anchor channels yields to a lower failure capacity compared to headed anchors. Welded anchors (headed anchors welded to a steel plate) and bonded anchors are also tested. Based on the test results, various fastening systems in concrete elements are compared.

\section{Key words:}

fastening systems, failure due to concrete fracturing, shear load, experimental testing, design recommendations

Prethodno priopćenje

\section{Natalija Bede, Philipp Grosser, Joško Ožbolt}

\section{Posmična nosivost različitih sustava pričvrščenja u betonskim elementima}

U radu su prikazani i analizirani rezultati ispitivanja u vezi s otkazivanjem nosivosti uslijed sloma betona različitih sustava pričvrščenja ugrađenih paralelno s rubom betonskog elementa i opterećenih na posmik u smjeru ruba betonskog elementa. Prema postojećim preporukama za proračun, otkazivanje nosivosti slomom betona je manje za sidrene profile nego za sidra s glavom u grupi. Ispitana su i zavarena sidra (sidra s glavom zavarena za čeličnu ploču) i kemijska sidra. Na osnovi dobivenih rezultata napravljena je usporedba različitih sustava pričvrščenja u betonskim elementima.

Ključne riječi:

sustavi pričvrščenja, otkazivanje uslijed sloma betona, posmično opterećenje, eksperimentalna ispitivanja, preporuke za proračun

Vorherige Mitteilung

Natalija Bede, Philipp Grosser, Joško Ožbolt

\section{Schubkraftragfähigkeit diverser Befestigungssysteme für Betonelemente}

In der Arbeit werden die Prüfergebnisse in Zusammenhang mit dem Versagen der Tragfähigkeit infolge von Betonbruch bei diversen Befestigungssystemen, die parallel mit dem Rand des Betonelements eingebaut und in Richtung seines Rands einer Schubbelastung ausgesetzt sind, dargestellt und analysiert. Laut den bestehenden Berechnungsempfehlungen ist das Versagen der Tragfähigkeit infolge von Betonbruch bei Verankerungsprofilen geringer als bei Ankern mit Köpfen in Gruppen. Untersucht wurden auch verschweißte Anker (Anker, die mit dem Kopf an eine Stahlplatte verschweißt wurden) und chemische Anker. Auf der Grundlage der gewonnenen Ergebnisse wurden diverse Befestigungssysteme für Betonelemente miteinander verglichen.

Schlüsselwörter:

Befestigungssysteme, Versagen infolge von Betonbruch, Schubbelastung, experimentelle Untersuchungen, Berechnungsempfehlungen 


\section{Introduction}

Significant developments have been made over the past decades in the field of fastening technology. The main purpose of fasteners is to connect different types of structural and non-structural elements, i.e. to enable connection between concrete members and the steel structure. There are different types of fasteners, such as headed anchors, chemical and mechanical post-installed anchors, and anchor channels. Anchors can be used as single fasteners or as a group of anchors. Anchor channels consist of at least two anchors. The main advantage of anchor channels is the flexibility of installation, i.e. the structure can be fixed at different positions. A typical application in which anchor channels are installed close to the edges of a concrete member is the fastening of curtain wall facades (see Figure 1). Due to the small edge distance, the steel capacity of the fastening system cannot fully be utilized and so the controlling failure mode is the concrete edge breakout. Currently, according to the design standards (DIN EN 1992-4 [2] and AC232 [3]), the calculated concrete breakout capacity of anchor channels yields to lower resistance compared to headed anchors for the same edge distance and member thickness. Main reasons for the reduced capacity of anchor channels are listed as follows:

- In design, an uneven load distribution to the anchors is assumed for anchor channels, whereas for headed anchors the shear load is evenly distributed to the anchors.

- For anchor channels, the critical spacing $\left(s_{c r, y}\right)$, the critical member thickness $\left(h_{\mathrm{cr}, \mathrm{V}}\right)$ and the critical corner distance $\left(c_{\mathrm{cr}, \mathrm{V}}\right)$ to ensure full breakout body, are assumed to be much larger compared to headed anchors. In the design of headed anchors $s_{c r, v}=3 c_{1}, h_{c r, v}=1.5 c_{1}$ and $c_{c r, v}=1.5 c_{1}$, while the following is valid for anchor channels $s_{\mathrm{cr}, \mathrm{V}}=4 c_{1}+2 b_{\mathrm{ch}} h_{\mathrm{cr}, \mathrm{V}}=$ $2 c_{1}+2 h_{\mathrm{ch}}$ and $c_{\mathrm{cr}, \mathrm{V}}=2 c_{1}+b_{\mathrm{ch}}\left(c_{1}=\right.$ edge distance, $h_{\mathrm{ch}}=$ channel height, $b_{\mathrm{ch}}=$ channel width).

- The basic equation for calculating the concrete edge breakout resistance of one anchor is different for anchor channels and headed anchors.

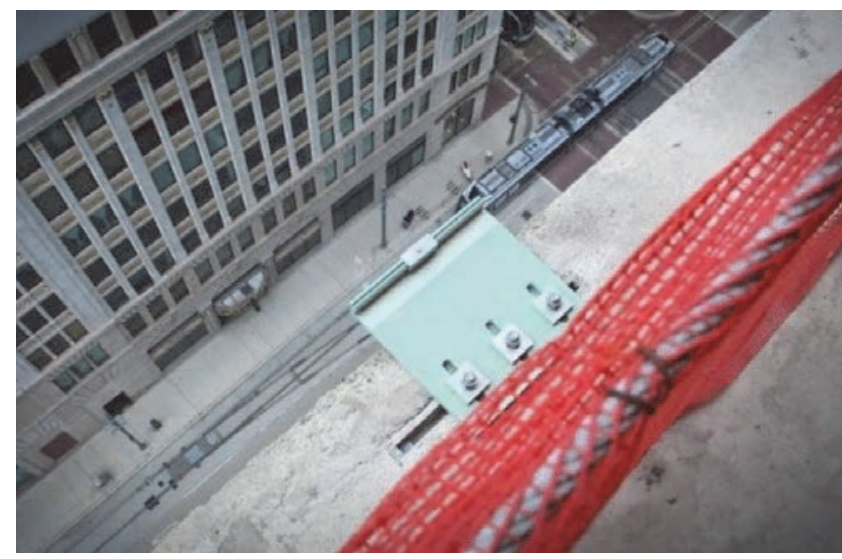

Figure 1. Application of anchor channel in facade construction [1]
Experimental investigations in uncracked concrete were performed with headed anchors, welded anchors, bonded anchors, and anchor channels, in order to understand the difference in concrete edge breakout capacity between fastening systems consisting of various types of anchors. Hence, in all tests, the edge distance $c$, the number of anchors in a group $n$, and the anchor spacing $s$ of the fastening system, as well as the concrete strength, were kept constant. For the tested parameters $(n=3, c=100 \mathrm{~mm}, s=150 \mathrm{~mm})$, according to DIN EN 1992-4 [2], the fastening with anchor channels leads to $30 \%$ higher utilization in design compared to the fastening with headed anchors for the same acting shear load. On the other hand, according to CEN/TS 1992-4 [4], headed anchors and anchor channels exhibit a comparable utilization in design. Therefore, the main motivation for performing the experiments presented in this paper was to improve the current design models. A comprehensive review of current design models is given in Eligehausen et al. [5]. It is important to note that a direct comparison of calculated resistances is not possible since the resistance of the entire group is calculated for headed anchors, whereas the most unfavourable anchor is verified for anchor channels. More details can be found in Grosser et al. [6]. Welded anchors (headed anchors welded to a steel plate embedded flush to the concrete surface) and bonded anchors were also tested for comparison purposes. Test specimens and test setup are described in detail in the first part of the paper. Experimental results are summarized in the second part. Finally, conclusions relating to current design are drawn based on test results.

\section{Experimental tests}

A total of 20 tests were performed at the Faculty of Civil Engineering in Rijeka, Croatia. The main aim of the tests was to investigate the difference in concrete shear breakout capacity of different fastening systems arranged close to concrete edges. Hence, to make the results comparable, all tests were performed in concrete slabs of the same mix composition, age, and concrete strength. In addition, the same geometrical parameters, such as edge distance, number of anchors, and anchor spacing, were used.

\subsection{Test specimens}

Four different fastening systems, headed anchors (Figure 2.a), welded anchors (Figure 2.b), anchor channels (Figure 2.c), and bonded anchors (Figure 2.d), were tested. The first three types of fasteners (headed anchors, welded anchors, and anchor channels) were cast in place, while bonded anchors were cut to the length of $160 \mathrm{~mm}$ from M16 threaded rods and postinstalled in the hardened concrete slab with the adhesive Hilti HIT-HY 200-A (Figure 2.d). More details can be found in [7].

A total of five concrete slabs were cast: four measuring 1600 $\mathrm{mm} \times 1600 \mathrm{~mm} \times 300 \mathrm{~mm}$ and one measuring $1600 \mathrm{~mm} \times$ 
$1600 \mathrm{~mm} \times 200 \mathrm{~mm}$. The specimens were cast in a wooden formwork. All tested slabs were reinforced with the wire-mesh Q 131 embedded near the top and bottom of concrete slabs for handling purposes (see Figure 3). Due to the wire position (approximately 200 $\mathrm{mm}$ away from the edges of the slab), the reinforcement did not affect the outcome of test results. All slabs were cast horizontally and compacted using a vibrator. The concrete specimens were stored in the laboratory of the Faculty of Civil Engineering, Rijeka, and wrapped with plastic sheets according to HRN EN 12390-2 [8] for 28 days. Afterwards, the plastic sheets were removed and concrete slabs were stored at an ambient temperature until the day of the testing.
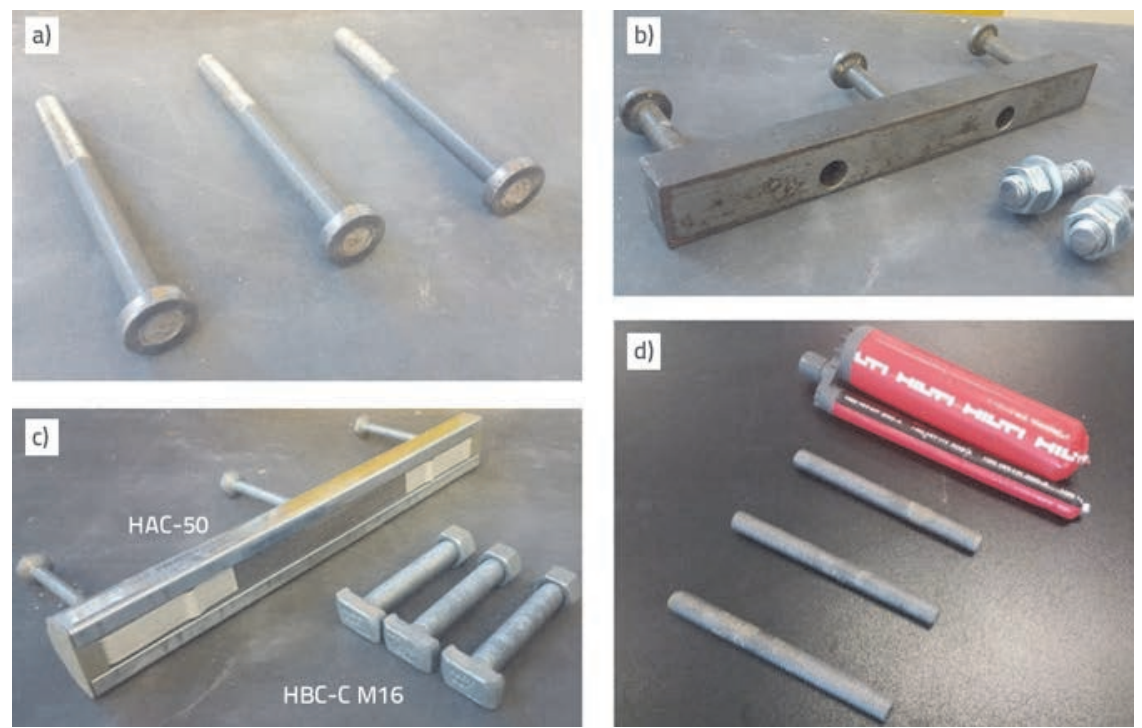

Figure 2. Fastening systems subjected to testing: a) headed anchors in CS1; b) welded anchors in CS2; c) anchor channels in CS3 and CS4; d) bonded anchors in CS5

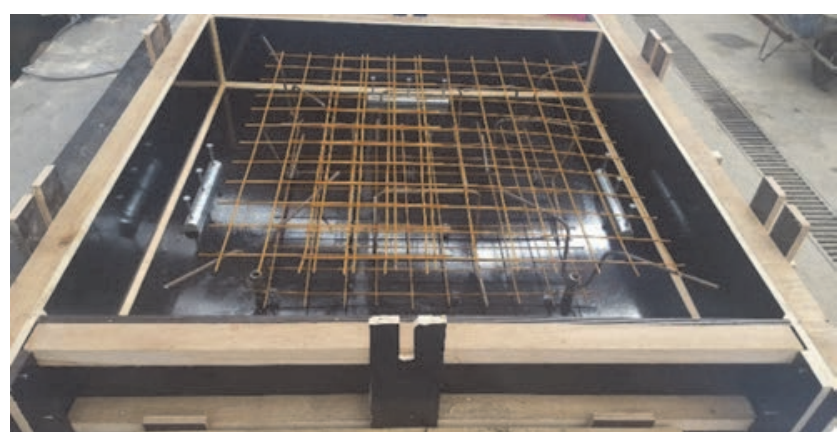

Figure 3. Reinforcement in concrete slabs
Detailed installation parameters for each fastening system in concrete are summarized in Table 1. Thus, it may be seen that four types of fastening systems were tested in $300 \mathrm{~mm}$ thick concrete slabs, while anchor channels were also tested in a $200 \mathrm{~mm}$ thick concrete slab. A schematic view of test specimens is given in Figure 4 for a group of headed anchors and for anchor channels. In all tests, the fastening systems were arranged parallel to the edge of the concrete slabs and subjected to shear load acting perpendicular to the edge. Each type of fastening system contained 3 anchors that are horizontally spaced at $150 \mathrm{~mm}$ intervals. All fastening systems were installed with the edge distance of $100 \mathrm{~mm}$. Headed

Table 1. Installation parameters

\begin{tabular}{|c|c|c|c|c|c|}
\hline Concrete slab ID & CS1 & CS2 & CS3 & CS4 & CS5 \\
\hline Fastening system & $\begin{array}{l}\text { headed } \\
\text { anchors }\end{array}$ & $\begin{array}{l}\text { welded } \\
\text { anchors }\end{array}$ & $\begin{array}{l}\text { anchor } \\
\text { channels }\end{array}$ & $\begin{array}{l}\text { anchor } \\
\text { channels }\end{array}$ & $\begin{array}{l}\text { bonded } \\
\text { anchors }\end{array}$ \\
\hline Slab thickness, $h[\mathrm{~mm}]$ & 300 & 300 & 300 & 200 & 300 \\
\hline Edge distance, $c[\mathrm{~mm}]$ & 100 & 100 & 100 & 100 & 100 \\
\hline Anchor spacing, s [mm] & 150 & 150 & 150 & 150 & 150 \\
\hline Embedment depth [mm] & 102 & 102 & 106 & 106 & 102 \\
\hline Diameter of anchors [mm] & 16 & 16 & 9 & 9 & 16 \\
\hline $\begin{array}{l}\text { Height of channel profile or welded steel plate } \\
\text { [mm] }\end{array}$ & - & 30 & 31 & 31 & - \\
\hline $\begin{array}{l}\text { Width of channel profile or welded steel plate } \\
\text { [mm] }\end{array}$ & - & 40 & 41.9 & 41.9 & - \\
\hline Net edge distance [mm] & - & 80 & 79 & 79 & - \\
\hline $\begin{array}{l}\text { Overlap of channel profile or welded steel plate } \\
\text { [mm] }\end{array}$ & - & 25 & 25 & 25 & - \\
\hline
\end{tabular}



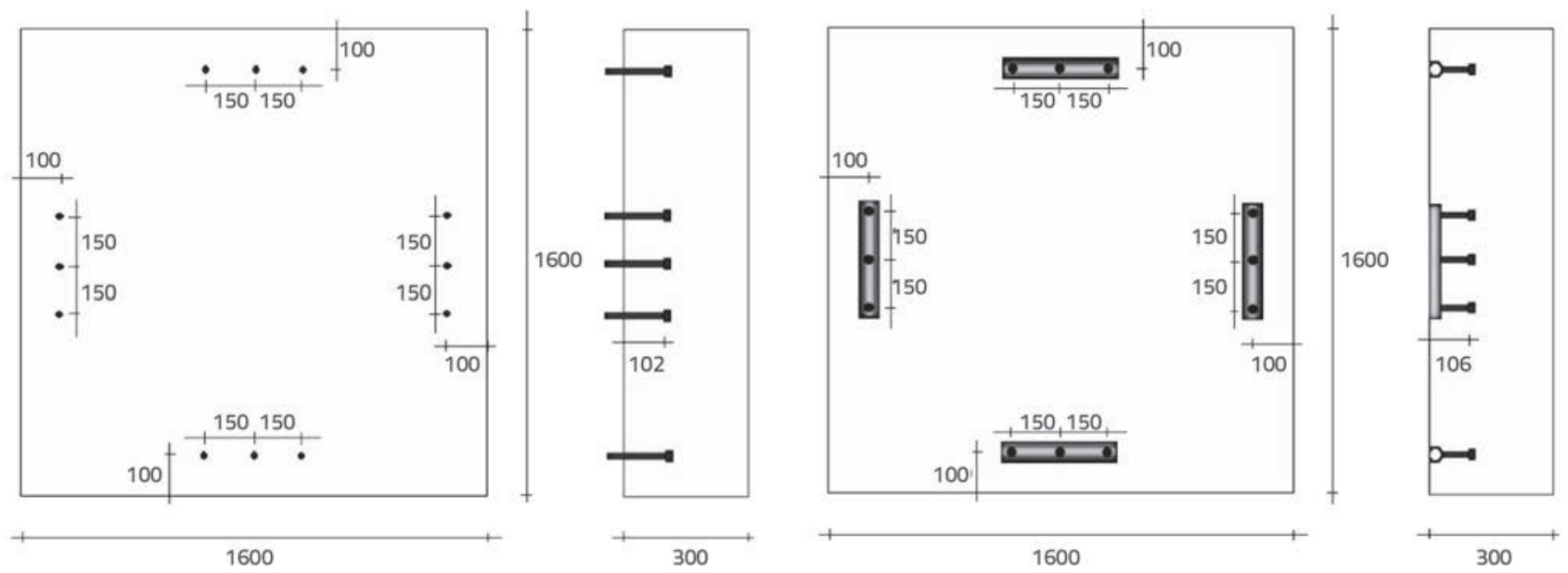

Figure 4. Test specimen (top and side view): headed anchors in CS1 (left); anchor channels in CS3 (right), all dimensions in mm

anchors, welded anchors and bonded anchors were installed with an embedment depth of $102 \mathrm{~mm}$, while the embedment depth of anchor channels amounted to $106 \mathrm{~mm}$.

\subsection{Material properties}

The normal weight low strength concrete (strength class C20/25) was used for all specimens. The concrete was produced according to requirements specified in HRN EN 2016 1:2006 and HRN 1128:2007. A single type of concrete mixture was used for all concrete slabs. The concrete consistency S2 was applied, and the maximum aggregate size of $16 \mathrm{~mm}$ was used. The concrete compressive strength was determined in accordance with HRN EN 12504-1:2009 [9] and HRN EN
12390-3:2009 [10] at the Faculty of Civil Engineering, Rijeka. Three cubes $150 \mathrm{~mm}$ in side length were made during casting of each slab. The concrete cubes were cured in a water tank for 28 days in accordance with HRN EN 12390-2 [8], and were then cured in air until testing. The compressive strength measured at the time of testing ranged between $31.22 \mathrm{MPa}$ and 44.78 MPa (average value: $38.33 \mathrm{MPa}$ ). However, to achieve the best representation of concrete strength, strength test specimens should be cured under the conditions identical to those applied for test slabs. Therefore, 3 concrete cylinders measuring 100 $\mathrm{mm}$ in diameter and $100 \mathrm{~mm}$ in height were taken from each concrete slab after completion of the respective test. The compressive strength measured on concrete specimens was converted into the cube strength using Eq. 2.1e of ETAG 001,

Table 2. Concrete compressive strength measured at day of testing on cored cylinders

\begin{tabular}{|c|c|c|c|c|c|c|}
\hline $\begin{array}{c}\text { Concrete slab } \\
\text { ID }\end{array}$ & Core ID & $\begin{array}{l}\text { Density } \\
{\left[\mathrm{kg} / \mathrm{m}^{3}\right]}\end{array}$ & $\begin{array}{c}\text { Core compressive } \\
\text { strength } \\
{[\mathrm{MPa}]}\end{array}$ & $\begin{array}{c}\text { Cube } \\
\text { compressive } \\
\text { strength [MPa] }\end{array}$ & $\begin{array}{l}\text { Average cube } \\
\text { compressive } \\
\text { strength [MPa] }\end{array}$ & $\begin{array}{c}\text { Average cylinder } \\
\text { compressive strength } \\
{[\mathrm{MPa}]}\end{array}$ \\
\hline \multirow{3}{*}{ CS1 } & 1 & 2287.1 & 31.58 & 33.24 & \multirow{3}{*}{33.15} & \multirow{3}{*}{26.52} \\
\hline & 2 & 2297.3 & 30.18 & 31.77 & & \\
\hline & 3 & 2275.9 & 32.72 & 34.44 & & \\
\hline \multirow{3}{*}{ CS2 } & 1 & 2260.0 & 33.46 & 35.22 & \multirow{3}{*}{35.78} & \multirow{3}{*}{28.62} \\
\hline & 2 & 2278.0 & 35.12 & 36.97 & & \\
\hline & 3 & 2293.5 & 33.38 & 35.14 & & \\
\hline \multirow{3}{*}{ CS3 } & 1 & 2268.9 & 31.94 & 33.62 & \multirow{3}{*}{32.50} & \multirow{3}{*}{26.00} \\
\hline & 2 & 2278.0 & 30.39 & 31.99 & & \\
\hline & 3 & 2260.0 & 30.30 & 31.89 & & \\
\hline \multirow{3}{*}{ CS4 } & 1 & 2206.8 & 30.32 & 31.92 & \multirow{3}{*}{32.52} & \multirow{3}{*}{26.02} \\
\hline & 2 & 2243.4 & 31.36 & 33.01 & & \\
\hline & 3 & 2221.5 & 31.01 & 32.64 & & \\
\hline \multirow{3}{*}{ CS5 } & 1 & 2249.2 & 32.89 & 34.62 & \multirow{3}{*}{34.10} & \multirow{3}{*}{27.28} \\
\hline & 2 & 2270.7 & 29.72 & 31.28 & & \\
\hline & 3 & 2307.8 & 34.57 & 36.39 & & \\
\hline
\end{tabular}


Annex A [11]. An average cube compressive strength amounted to $33.61 \mathrm{MPa}$ (results ranged from $31.28 \mathrm{MPa}$ to $36.97 \mathrm{MPa}$ ). The cube compressive strength was converted into the strength of cylinders using relation given in ETAG 001, Annex A, Eq. 2.1a [11]. Fifteen specimens in total were tested. All results are summarized in Table 2.

\subsection{Test setup and instrumentation}

The tests were carried out in the laboratory of the Faculty of Civil Engineering in Rijeka on a strong floor equipped with a ZWICK ROELL hydraulic actuator, type LH 0250-100, with a 250 kN load cell. The photo of the typical test setup and measuring instrumentation is given in Figure 5. To ensure a fixed position of the concrete slab during testing, a special steel frame was designed and manufactured. The steel frame was placed in front of the hydraulic actuator, mounted to a strong floor with steel rods (M20, 8.8 CS) and supported at the front side to avoid movement during testing. The concrete slabs were placed on top of the steel frame and mounted as shown in Figure 5, to avoid upward displacement during testing. A servo hydraulic actuator was used to apply shear load by means of a $30 \mathrm{~mm}$ thick loading plate, which was connected to the actuator with a threaded M20 rod. Depending on the fastening system tested, the loading plate was connected directly to the anchors (Figure 6.a) or channel bolts (Figure 6.b), or connected with M20 adapter bolts in case of welded anchors (Figure 6.c). A torque moment of $60 \mathrm{Nm}$ was applied to each fastening system. To reduce friction, a Teflon sheet $2 \mathrm{~mm}$ in thickness was placed between concrete and the loading plate.

The horizontal displacement in the direction of shear load was measured using displacement transducers type LD 320-50 OMEGA. Two LVDTs were glued to the concrete surface behind the outermost anchors (see Figure 5). The anchor displacement was determined by averaging two LVDTs measurements. The anchor shear load was measured using the load cell type BPSTL0250.10.00 (max load 250 kN) (see Figure 5).

The tests were performed at room temperature. The age of concrete at the time of testing was approximately 2 months. For all tests, the spacing of concrete support blocks was defined to ensure sufficient distance so as to enable complete

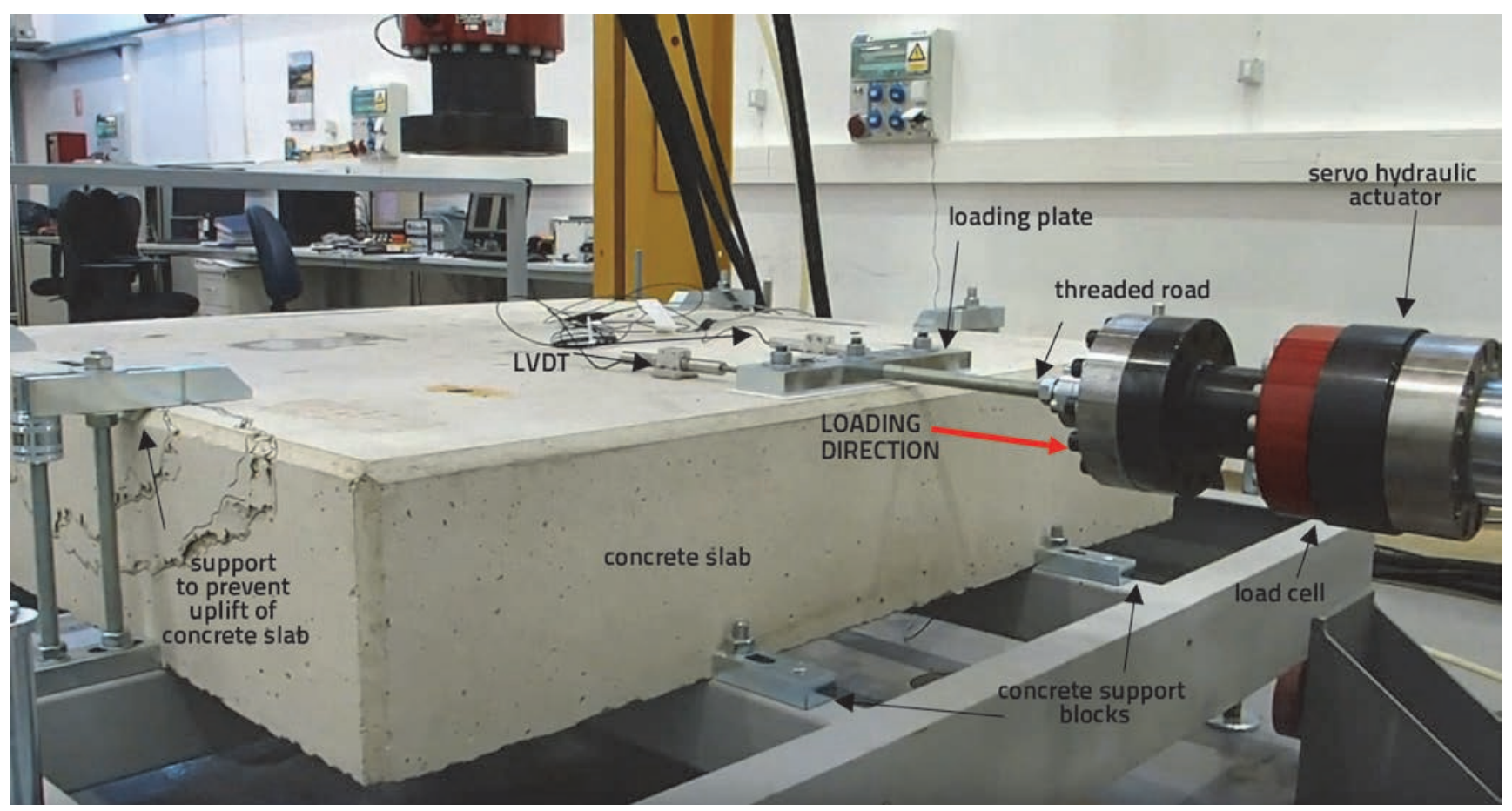

Figure 5. Typical test setup

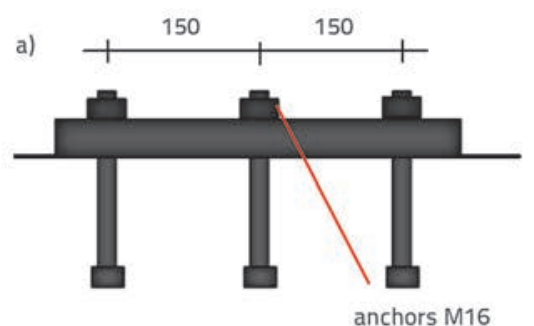

anchors M16

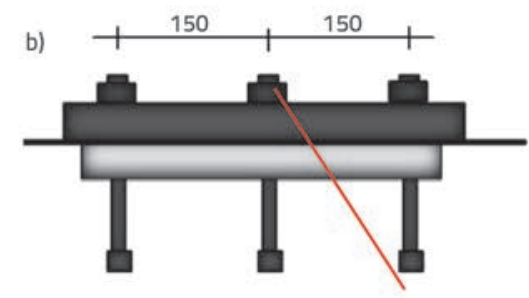

channel bolts HBC-C M16

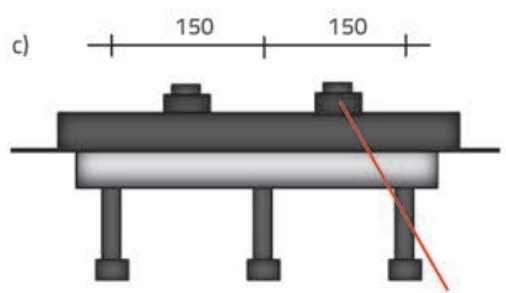

adapter bolts $\mathrm{M} 20$

Figure 6. Connection between fastening system and loading plate for: a) headed anchors; b) anchor channels; c) welded anchors 
Table 3. Summary of test results

\begin{tabular}{|c|c|c|c|c|c|c|}
\hline \multicolumn{2}{|c|}{ Concrete slab ID } & $\begin{array}{c}\text { CS1 } \\
(h=300 \mathrm{~mm})\end{array}$ & $\begin{array}{c}\text { CS2 } \\
(h=300 \mathrm{~mm})\end{array}$ & $\begin{array}{c}\text { CS3 } \\
(h=300 \mathrm{~mm})\end{array}$ & $\begin{array}{c}\text { CS4 } \\
(h=200 \mathrm{~mm})\end{array}$ & $\begin{array}{c}\text { CS5 } \\
(h=300 \mathrm{~mm})\end{array}$ \\
\hline \multicolumn{2}{|c|}{ Fastening system } & Headed anchors & Welded anchors & Anchor channel & Anchor channel & Bonded anchors \\
\hline \multicolumn{7}{|c|}{ Ultimate load [kN] } \\
\hline \multirow{4}{*}{$\begin{array}{c}\text { Test } \\
\text { series }\end{array}$} & 1 & 45.82 & 49.54 & 44.58 & 37.21 & 57.95 \\
\hline & 2 & 48.15 & 53.77 & 41.83 & 38.13 & 51.33 \\
\hline & 3 & 46.45 & 54.48 & 45.62 & 37.28 & 50.24 \\
\hline & 4 & 46.97 & 45.44 & 44.72 & 37.18 & 48.50 \\
\hline \multicolumn{2}{|c|}{ Mean value ${ }^{1}$} & 46.85 & 50.81 & 44.19 & 37.45 & 52.00 \\
\hline
\end{tabular}

development of failure cone. Tests were repeated four times per test series. Shear load was applied by controlling hydraulic actuator displacement at the constant displacement rate of $0.02 \mathrm{~mm} / \mathrm{s}$, and so the peak load was reached in approximately 3 to 5 minutes (quasi-static tests). During each test, anchor loads and displacement measurements were recorded with the sampling rate of $100 \mathrm{~Hz}$ and collected via a data acquisition system (National Instruments).

\section{Test results}

\subsection{Load-displacement curves}

The measured ultimate loads for each test series are summarized in Table 3, and the measured load-displacement curves for each test series are plotted in Figure 7. Note that slip can occur in this type of testing, as can be seen in the measured load- displacement curves. It can lead to different peak displacements and curve shapes (compare CS3-1 and CS5-3 in Figure 7). The reasons can vary, e.g. it can be due to slip of the loading plate, activation of the anchors and anchor channels that can be nonsymmetric, local failure and crushing of concrete, and frictional effects. Test results show that the ultimate strength of headed anchors and anchor channels is approximately the same in the $300 \mathrm{~mm}$ thick concrete slabs. Compared to headed anchors (CS1) and anchor channels (CS3), the tests with welded anchors (CS2) exhibit approximately 10\% higher ultimate strength results. Furthermore, it is interesting to note that in the case of bonded anchors (CS5), the measured ultimate strength is also by about $10 \%$ higher compared to headed anchors (CS1). Generally, the failure mode is of brittle type and is due to the failure of concrete in tension. In terms of ductility, it can be observed that headed anchors (CS1) and bonded anchors (CS5) exhibit relatively brittle post-peak response whereas the post-peak
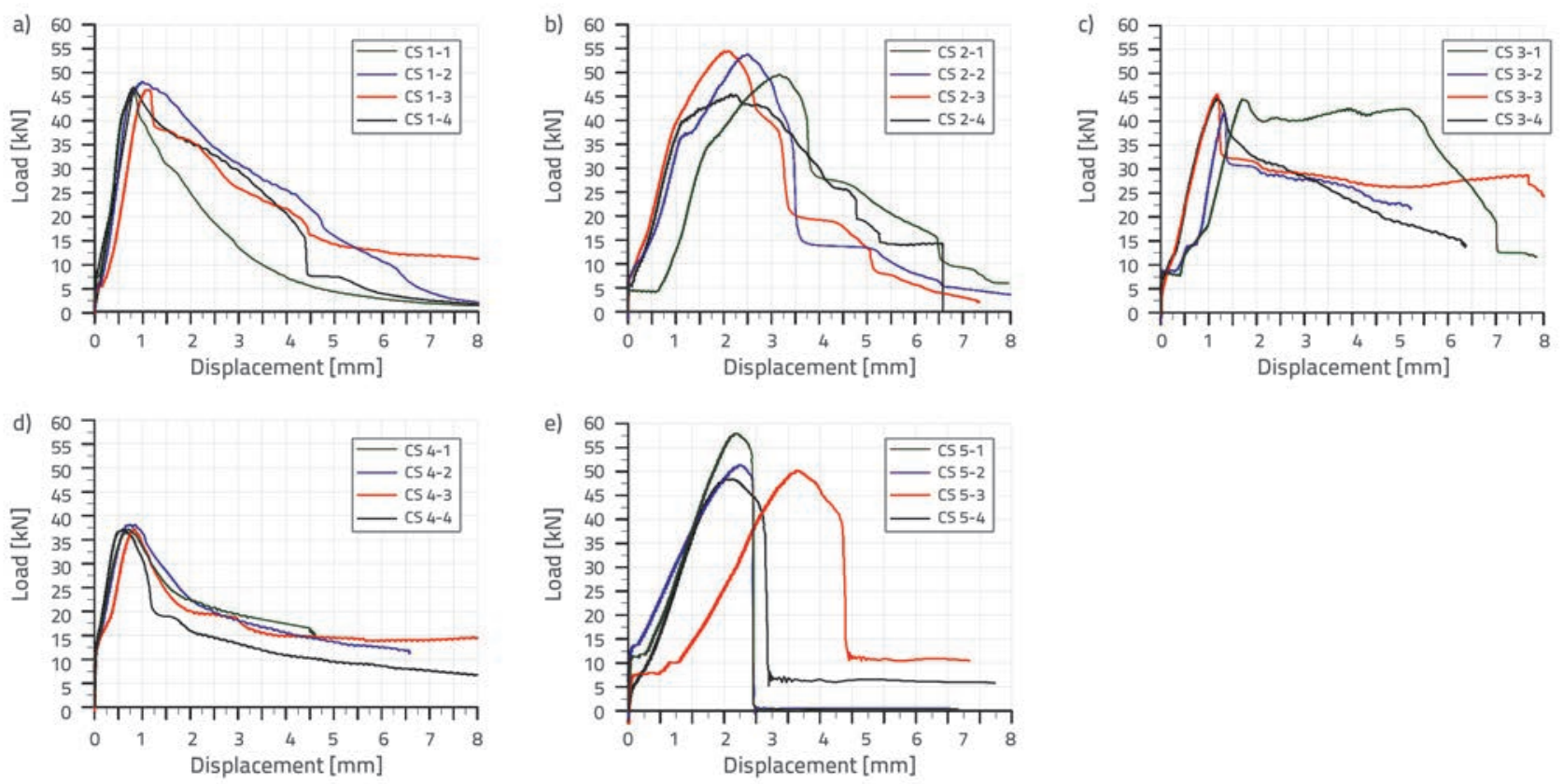

Figure 7. Load-displacement curves of fastening systems: a) headed anchors in CS1 $(h=300 \mathrm{~mm})$; b) welded anchors in CS2 ( $h=300 \mathrm{~mm})$; c) anchor channels in CS3 $(h=300 \mathrm{~mm})$; d) anchor channels in CS4 $(h=200 \mathrm{~mm})$; e) bonded anchors in CS5 $(h=300 \mathrm{~mm})$ 
response of welded anchors (CS2) and especially that of anchor channels (CS3, CS4) is more ductile. Note that, from the fracture mechanics point of view, the concrete cone failure of fasteners belongs to the category of negative geometry (the stress intensity factor decreases with an increase in crack length) where concrete fracture energy is more relevant for the resistance than the tensile strength of concrete. Compared to the positive geometry (e.g. threepoint bending), their response is more ductile. However, compared to the failure of reinforced concrete, the fasteners are generally less ductile.

\subsection{Failure patterns}

The concrete edge failure was observed in all tests. Typical breakout patterns for each type of fastening system are shown in Figure 8. As expected, the breakout pattern is similar in all tests. However, it can be observed that the crack starts from the steel plate or channel profile in case of welded anchors (CS2) and anchor channels (CS3 and CS4), which leads to a smaller breakout body due to the smaller net edge distance $\left(c^{-}=c-b_{c h} / 2\right)$. During the testing, it was observed that in case of welded anchors further concrete cracking appears from the back edge of the steel plate (red lines in Figure 8.b) soon after initial concrete cone crack formation (black lines in Figure 8.b). A full concrete breakout cone developed for all fastening systems tested in $300 \mathrm{~mm}$ thick concrete slabs. In case of anchor channels tested in a 200 $\mathrm{mm}$ thick concrete slab, the concrete breakout cone is truncated by the lower edge of the concrete slab, which explains reduced capacity observed in test series CS4.

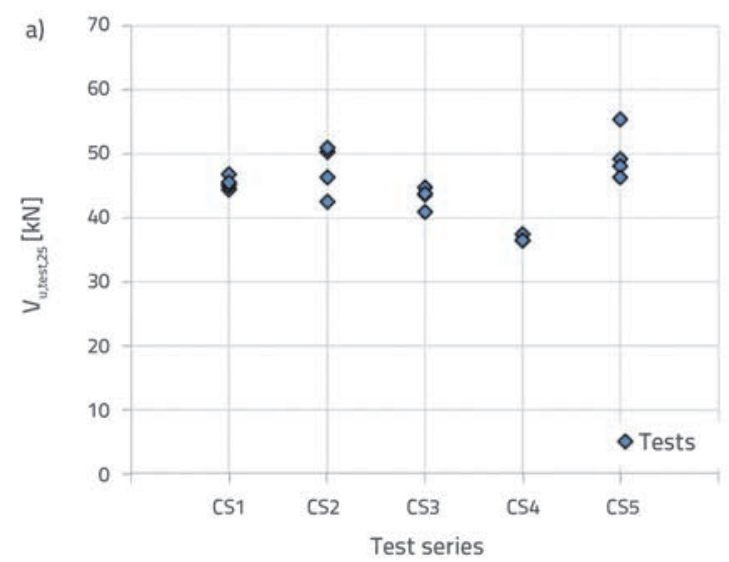

\section{Comparison of test results}

To allow a direct comparison between the fastening systems, all test results were normalized to a concrete compressive strength measured on cylinder $f_{c}=25 \mathrm{MPa}$ (Figure 9.a). Therefore, in order to account for the different concrete strengths, the peak loads were scaled with the factor $\left(25 / f_{\mathrm{cm}}\right){ }^{0.5}$, where $f_{\mathrm{cm}}$ is the mean cylinder strength of concrete, as given in Table 2. This kind of scaling is due to the fact that the breakout resistance in design is taken as the square root function of the concrete compressive strength. The related failure loads (the ratio of ultimate strength

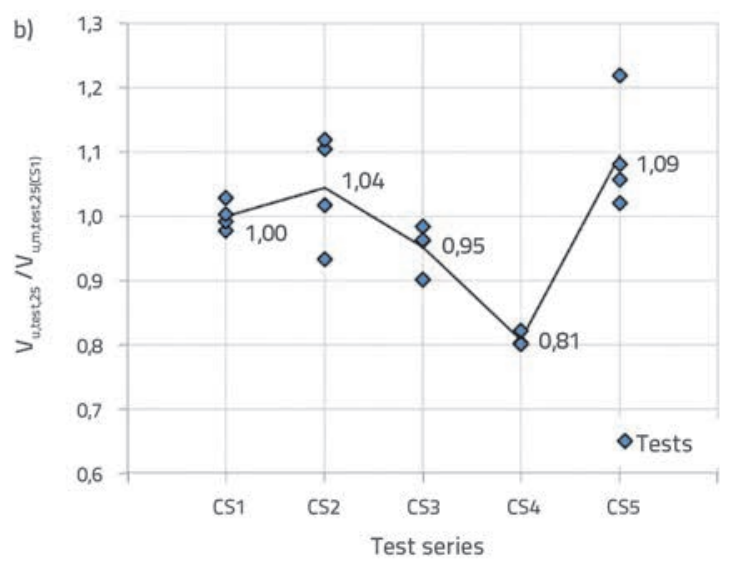

Figure 9. a) Failure loads normalized to $f_{c}=25 \mathrm{MPa}$; b) ratio of failure loads to mean failure load of test series CS1 
$\mathrm{V}_{\text {utest } 25}$ to mean ultimate strength calculated from the test series CS1 $\mathrm{V}_{\text {u,m,test,25 (CS1) }}$ ) are shown in Figure 9.b. Anchor channels tested in a $300 \mathrm{~mm}$ thick concrete slab (CS3) show a slightly lower ultimate strength compared to headed anchors (CS1). This can be attributed to the smaller anchor diameter for anchor channels. M16 anchors were used for headed anchors and welded anchors, whereas the anchor diameter of anchor channels amounted to 9 mm only. According to DIN EN 1992-4 [2], for an edge distance of $100 \mathrm{~mm}$, the concrete breakout strength of a $9 \mathrm{~mm}$ anchor is approximately $10 \%$ lower compared to the concrete breakout strength calculated for an anchor $16 \mathrm{~mm}$ in diameter. The tests with welded anchors (CS2) reveal approximately 5\% higher ultimate strength compared to headed anchors (CS1). The steel plate of the welded anchors has the same dimensions (width, height and length) as the channel of the anchor channel (see Table 1). Therefore, the welded anchors can be considered as an anchor channel with infinite rigidity.

Current design standards (DIN EN 1992-4 [2] and AC232 [3]) take into account the influence of member thickness in case of anchor channels through reduction factor $\psi_{\mathrm{ch,h,v^{* }},}$ In case of the tested anchor channels in a $200 \mathrm{~mm}$ thick concrete slab with $100 \mathrm{~mm}$ edge distance, Eq. (1) leads to the approximately $15 \%$ reduction of the calculated concrete breakout strength.

$\psi_{c h, h, V}=\left(\frac{h}{h_{c r, V}}\right)^{0.5} \leq 1.0$ gdje je $h_{c r, v}=2 c_{1}+2 h_{c h}$

According to DIN EN 1992-4 [2] there should be no difference between headed anchors and bonded anchors. However, tests with bonded anchors show a 10\% higher ultimate strength in shear compared to headed anchors.

\section{REFERENCES}

[1] Anchor channel, www.hilti.com/anchor-systems/cast-inanchors/r4809, 05.07.2017.

[2] DIN EN 1992-4: Eurocode 2 - Design of concrete structures Part 4: Design of fastenings for use in concrete. Final draft, 2017.

[3] AC232: Acceptance Criteria for anchor channels in concrete elements. ICC-ES, previously approved October 2016, proposed April 2017.

[4] CEN/TS 1992-4:2009 or DIN SPEC 1021-4:2009-08: Design of fastenings for use in concrete. Part 4-1: General, Part 4-2: Headed fasteners, Part 4-3: Anchor channels, Part 4-4: Postinstalled fasteners - Mechanical systems, Part 4-5: Post-installed fasteners - Chemical systems, 2009.

[5] Eligehausen, R., Mallée, R., Silva, J.F.: Anchorage in Concrete Construction, Ernst \& Sohn, Berlin, 2006.

[6] Grosser, P., Basche, H.: Design of anchor channels subjected to shear loads close to edges of a concrete member, Heft 615, Erläuterungen zu DIN EN 1992-4 - Bemessung der Verankerung von Befestigungen in Beton, Deutsche Ausschuss für Stahlbeton (DAfStb).

\section{Conclusions}

The main aim of the research presented in the paper was to investigate the difference in concrete breakout strength of anchor channels and headed anchors in uncracked concrete. According to DIN EN 1992-4 [2], the design of anchor channels for the concrete edge failure mode leads, for the investigated parameters, to $30 \%$ higher utilization compared to the design of headed anchors, whereas according to CEN/TS 1992-4 [4] headed anchors and anchor channels lead to comparable utilization in design. Experimental test results show that the shear breakout strength of anchor channels is comparable to headed anchors for the same parameters. Planning engineers are now faced with the question of how a cost-efficient solution for anchor channels can be obtained with the design according to DIN EN 1992-4 [2] and AC232 [3]. The discrepancy between headed anchors and anchor channels needs to be corrected in the current design codes. However, further experimental and numerical studies are required in this respect.

\section{Acknowledgement}

The authors are grateful to the Faculty of Civil Engineering in Rijeka for providing equipment for conducting this testing. The financial and technical support was provided by Hilti AG. Testing equipment at the Faculty of Civil Engineering in Rijeka was purchased under the project Research Infrastructure for Campus-based Laboratories at the University of Rijeka, number RC.2.2.06-0001, which was co-funded from the European Fund for Regional Development (ERDF).
[7] Bede, N.: Report on laboratory testing of headed anchors, welded embeds, bonded anchors and anchor channels close to edges of a concrete slab, Faculty of Civil Engineering, University of Rijeka, Croatia, 2017.

[8] HRN EN 12390-2: Testing hardened concrete - Part 2: Making and curing specimens for strength test, Croatian Standards Institute, Zagreb, 2009.

[9] HRN EN 12504-1: Testing concrete in structures. Cored specimens. Taking, examining and testing in compression, Croatian Standards Institute, Zagreb, 2009.

[10] HRN EN 12390-3: Testing hardened concrete - Part 3: Compressive strength of test specimens, Croatian Standards Institute, Zagreb, 2009.

[11] EOTA 2012: ETAG 001. Guideline for European technical approval of metal anchors for use in concrete, 2012. 